\title{
Kemampuan Sabun Antiseptik Cair yang Mengandung Triclosan yang Terdaftar di BPOM dalam Menghambat Pertumbuhan Bakteri Escherichia coli
}

\author{
Marhamah $^{1}$, Sri Ujiani' ${ }^{2}$, Maria Tuntun ${ }^{3}$ \\ 1,2,3 Jurusan Analis Kesehatan, Politeknik Kesehatan Tanjungkarang, Indonesia \\ Email: marhamahaja@gmail.com
}

\begin{abstract}
Ability of Liquid Antiseptic Soap Containing Triclosan Registered at BPOM in Inhibiting Escherichia coli Bacterial Growth. In the community, there is still circulating hand washing soap containing triclosan and registered with BPOM/Ministry of Health, but the packaging is not printed how many milliliters of water should be added so that the concentration is not effective in killing bacteria on the hand. The purpose of this study was to determine the ability of liquid antiseptic soap containing triclosan registered at BPOM/Ministry of Health in inhibiting the growth of Escherichia coli bacteria and bacteria on the hands. The research was carried out at the Bacteriology Laboratory of the Department of Health Analyst at Tanjungkarang Health Polytechnic and Lampung Veterinary Center in July-November 2017. This type of research was a completely randomized design. Pre-experiment of one group pre-post-test, the test method of Total Plate Numbers (ALT). Test uses concentrations of 2\%, 4\%, 6\%,8\% and 10\% with 5 repetitions. The results showed the strength of liquid antiseptic soap containing triclosan with a concentration of $2 \%, 4 \%, 6 \%, 8 \%$ and $10 \%$ including the criteria of being moderate and effective in killing bacteria on the hand with a decrease in germ number $96.18 \%$. The Anova test obtained p-value 0,000 , meaning that there was an effect of the concentration of liquid antiseptic soap on the growth of Escherichia coli bacteria. The LSD test results showed a significant difference between each liquid antiseptic soap concentration (p-value 0,000-0,024) in inhibiting bacterial growth. The results of the T-test showed that there were differences in the number of germs (ALT) in the hands before and after hand washing with liquid antiseptic soap.
\end{abstract}

Keywords: Antiseptic soap, Escherichia coli, Triclosan

\begin{abstract}
Abstrak: Kemampuan Sabun Antiseptik Cair yang Mengandung Triclosan yang Terdaftar di BPOM dalam Menghambat Pertumbuhan Bakteri Escherichia coli. Di masyarakat masih beredar sabun cuci tangan yang mengandung triclosan dan terdaftar di BPOM/Kemenkes, namun dikemasan tidak tertera berapa mililiter air yang harus ditambahkan, sehingga tidak terukur konsentrasi yang efektif dalam membunuh bakteri pada tangan. Tujuan penelitian ini mengetahui kemampuan sabun antiseptik cair yang mengandung triclosan yang terdaftar di BPOM/Kemenkes dalam menghambat pertumbuhan bakteri Escherichia coli dan bakteri pada tangan. Desain penelitian eksperimen, dengan rancangan acak lengkap. Pra eksperimen one group pre-test posttest, metode pemeriksaan Angka Lempeng Total (ALT). Pemeriksaan daya hambat menggunakan konsentrasi $2 \%, 4 \%, 6 \%, 8 \%$ dan $10 \%$ dengan 5 kali pengulangan. Hasil penelitian menunjukkan kekuatan sabun antiseptik cair yang mengandung triclosan dengan konsentrasi $2 \%, 4 \%, 6 \%, 8 \%$ dan $10 \%$ termasuk kriteria sedang dan efektif dalam membunuh bakteri pada tangan dengan penurunan angka kuman 96,18 \%. Pada uji Anova didapatkan p-value 0,000, ada pengaruh konsentrasi sabun antiseptik cair terhadap pertumbuhan bakteri Escherichia coli. Hasil uji LSD, ada perbedaan yang bermakna antara tiap konsentrasi sabun antiseptik cair ( $p$-value 0,000-0,024) dalam menghambat pertumbuhan bakteri. Hasil uji T menunjukkan ada perbedaan jumlah kuman (ALT) pada tangan sebelum dan sesudah cuci tangan dengan sabun antiseptik cair.
\end{abstract}

Kata Kunci: Sabun antiseptik, Escherichia coli, Triclosan

\section{PENDAHULUAN}

Beberapa tahun belakangan ini bermunculan berbagai produk sabun yang mengandung zat antiseptik. Banyak produk yang dikembangkan dari sabun yaitu sabun cuci tangan, sabun mandi, pencuci muka, pembersih khusus wanita, pencuci piring dan alat rumah tangga. Salah satu bentuk sabun yang mengandung antiseptik adalah sabun cair. Mencuci tangan dengan sabun cair, banyak 
disukai oleh masyarakat, karena sabun cair lebih praktis penggunaannya dan lebih mudah dalam penyimpanannya (Widodo, dkk, 2007).

Sabun cair antiseptik mengandung suatu antiseptikum yang berguna untuk memperkuat daya anti bakterinya. Hanya beberapa zat saja yang dapat digunakan untuk tujuan ini, yaitu triclosan, heksalorofen dan bithionol (Tjay dan Kirana, 2007).

Nugraha A.P (2016) menyatakan bahwa bahan triclosan yang biasa digunakan dalam sabun antiseptik telah dikaitkan dengan isu-isu kesehatan termasuk resistensi antibiotik, alergi dan gangguan pada sistem hormon mamalia. Kadar triclosan yang diperbolehkan dalam sabun antiseptik kurang dari 0,3\%. Jika dalam penggunaannya konsentrasi yang dipakai terlalu tinggi atau berlebihan atau pun terlalu rendah dapat menyebabkan bakteri resistensi terhadap triclosan.

Hasil observasi di Kota Bandar Lampung masih ditemukan sabun antiseptik cair yang mengandung triclosan, terdaftar di BPOM maupun Dinas Kesehatan. Masyarakat pada umumnya menggunakan sabun cair dengan menambahkan air untuk mengencerkan sabun, namun pada kemasan sabun cair tersebut, tidak tertera penjelasan volume air yang harus ditambahkan dalam pemakaian, sehingga tidak terukur konsentrasi sabun antiseptik yang digunakan. Jika air yang ditambahkan pada antiseptik sedikit maka bakteri pada tangan dapat bertahan hidup, dan lama-lama bakteri pada tangan akan resisten terhadap antiseptik

Penggunaan sabun antiseptik bertujuan untuk kebersihan tangan dan atau untuk membunuh bakteri yang ada di tangan. Tangan berperan dalam rantai penularan penyakit infeksi, sehingga menjaga kebersihan kulit tangan setiap saat sangat penting untuk pencegahan infeksi, seperti infeksi bakteri gastrointestinal (bakteri yang menginfeksi saluran pencernaan) yaitu; Salmonella, Shigella, Vibrio dan Escherichia coli.

Bakteri Escherichia coli merupakan kelompok bakteri coliform yang digunakan sebagai indikator pencemaran, dimana jika suatu bahan/spesimen ditemukan bakteri Escherichia coli, kemungkinan pada spesimen tersebut ada bakteri yang menginfeksi saluran pencernaan yaitu bakteri enteropatogenik dan atau bakteri toksigenik (Fardiaz, 1993; Chandra. B, 2007).

Tujuan penelitian ini adalah:

1. Mengetahui kemampuan sabun antiseptik cair mengandung triclosan konsentrasi $2 \%, 4 \%$, $6 \%, 8 \%$ dan $10 \%$ yang terdaftar di BPOM/
Kemenkes dalam menghambat pertumbuhan bakteri Escherichia coli.

2. Mengetahui kekuatan sabun antiseptik cair mengandung triclosan konsentrasi 2\%, 4\%, $6 \%$, $8 \%$ dan $10 \%$ yang terdaftar di BPOM/ Kemenkes dalam menghambat pertumbuhan bakteri Escherichia coli.

3. Mengetahui kekuatan sabun antiseptik cair mengandung triclosan konsentrasi $2 \%, 4 \%$, $6 \%, 8 \%$ dan $10 \%$ yang terdaftar di BPOM/ Kemenkes dalam menghambat pertumbuhan bakteri Escherichia coli dibandingkan dengan fenol $2 \%$ sebagai kontrol positif.

4. Mengetahui sabun antiseptik cair mengandung triclosan konsentrasi 2\%, 4\%, 6\%, 8\% dan $10 \%$ yang terdaftar di BPOM/ Kemenkes yang paling besar kemampuanya dalam menghambat pertumbuhan bakteri Escherichia coli.

5. Mengetahui jumlah angka kuman /ALT pada tangan sebelum dan sesudah tangan dicuci dengan sabun antiseptik cair mengandung triclosan yang terdaftar di BPOM/ Kemenkes.

6. Mengetahui jumlah penurunan angka kuman dan persentase penurunan angka kuman /ALT pada tangan sesudah tangan dicuci dengan sabun antiseptik cair mengandung triclosan yang terdaftar di BPOM/ Kemenkes

7. Mengetahui efektifitas sabun antiseptik cair mengandung triclosan dan terdaftar di BPOM/Kemenkes dalam membunuh bakteri pada tangan.

\section{METODE}

Desain penelitian ini eksperimen, dengan rancangan acak lengkap dan pra eksperimen one group pre-test post-test. Variabel bebas yaitu sabun antiseptik cair cuci tangan, sedangkan variabel terikat bakteri Escherichia coli dan jumlah angka kuman pada tangan (Notoatmodjo, 2005).

Penelitian dilakukan di Laboratorium Bakteriologi Jurusan Analis Kesehatan Poltekkes Tanjungkarang dan Laboratorium Balai Veteriner Lampung dengan waktu penelitian bulan JuliNovember 2017.

Penelitian ini dilakukan dalam 2 tahap, yaitu pra-eksperimen dengan melakukan pemeriksaan angka kuman metode pemeriksaan ALT (Angka Lempeng Total) pada tangan sebelum dan sesudah dicuci dengan sabun antiseptik cair. Tahap berikutnya adalah uji daya hambat dengan metode difusi cara Kirby Bauer untuk menentukan kekuatan sabun antiseptic (Soemarno, 2000). 
Pemeriksaan angka kuman (ALT) menggunakan subjek penelitian adalah telapak tangan dari 30 orang probandus. Sebelum dicuci dengan antiseptik, tangan probandus dipulas dengan lidi kapas steril, lalu lidi kapas ini dimasukkan dalam $9 \mathrm{ml}$ pengencer steril (buffer phosphat), lalu dihomogenkan (pengenceran $10 \mathrm{x}$ ), dari pengenceran yang $10 \mathrm{x}$ ini diambil $1 \mathrm{ml}$, dimasukkan dalam 9ml buffer phosphat, kemudian dihomogenkan (pengenceran 100x), demikian seterusnya sampai pengenceran 100.000 kali. Sesudah dicuci dengan antiseptik perlakuannya sama dengan sebelum cuci tangan dengan sabun antiseptik.

Jumlah kuman (ALT) pada tangan sebelum dan sesudah cuci tangan dengan antiseptik dihitung dengan rumus sebagai berikut:

$$
\operatorname{ALT}=\frac{\left\{\left(\mathrm{A}_{1}-\mathrm{C}\right) \times \mathrm{P}_{1}\right\}+\ldots . .+\left\{\left(\mathrm{A}_{\mathrm{n}}-\mathrm{C}\right) \times \mathrm{P}_{\mathrm{n}}\right\}}{\mathrm{N}}
$$

Keterangan :

$\mathrm{A}=$ Jumlah koloni kuman pada petri pengenceran

$\mathrm{C}=$ Jumlah koloni pada petri control

$\mathrm{P}=$ Faktor pengenceran

$\mathrm{N}=$ Jumlah petri yang koloninya 30-300 koloni

Data hasil ALT yang didapat dianalisis secara univariat dan bivariat. Analisis univariat dilakukan untuk menentukan persentase penurunan angka kuman sebelum cuci tangan dengan sesudah cuci tangan memakai sabun antiseptik cair. Analisis bivariat menggunakan uji $\mathrm{T}$ one tail, untuk menentukan efektifitas sabun antiseptik cair yang mengandung triclosan. Jika $\mathrm{T}_{\text {hitung }}>\mathrm{T}_{\text {tabel }}$ berarti ada pengaruh bermakna terhadap angka kuman pada tangan sebelum cuci tangan dengan sesudah cuci tangan dengan sabun antiseptik.

Pemeriksaan uji daya hambat menggunakan bakteri Echerichia coli dan sabun cair cuci tangan mengandung antiseptik triclosan yang terdaftar di BPOM atau Kemenkes, yang diencerkan pada konsentrasi 2\%, 4\%, 6\%, $8 \%$ dan 10\%. Masingmasing pengenceran diulang sebanyak 5 kali, didapat dari rumus (t-1) (r-1) $\geq 15$ : (t=jumlah perlakuan; $r=j u m l a h$ pengulangan). Sebagai kontrol negatif menggunakan aquades steril dan kontrol positif/pembanding menggunakan fenol $2 \%$.

Diameter zona hambat yang terbentuk dari masing-masing perlakuan (konsentrasi antiseptik $2 \%, 4 \%, 6 \%, 8 \%, 10 \%)$, kontrol negatif dan kontrol positif yang diulang sebanyak 5 kali, dibagi lima sehingga didapatkan rata-rata diameter zona hambat antiseptik pada konsentrasi $2 \%, 4 \%, 6 \%, 8 \%$ dan $10 \%$ yang disajikan dalam bentuk tabel.
Analisa data hasil uji daya hambat dilakukan tiga tahap yaitu analisa data univariat yaitu mengukur rata-rata diameter zona hambat sabun antiseptik cair yang mengandung triclosan terhadap bakteri Echerichia coli, lalu ditentukan kriteria sabun antiseptik tersebut, termasuk sangat kuat, kuat, sedang atau lemah, lalu dibandingkan dengan fenol $2 \%$ sebagai standar positif.

Analisa data bivariat menggunakan uji Anova (Analysis of varian) untuk menentukan pengaruh sabun antiseptik konsentrasi 2\%, $4 \%$, $6 \%, 8 \%$ dan $10 \%$ terhadap pertumbuhan bakteri Echerichia coli. Jika p-value $>5 \%(0,05)$ berarti sabun antiseptik konsentrasi 2\%, 4\%,6\%,8\% dan $10 \%$ tidak memperlihatkan pengaruh yang bermakna terhadap pertumbuhan bakteri Echerichia coli, namun jika p-value $<\alpha(0,05)$ berarti sabun antiseptik konsentrasi $2 \%, 4 \%, 6 \%$, $8 \%$ dan $10 \%$ memperlihatkan pengaruh yang bermakna terhadap pertumbuhan bakteri Echerichia coli.

Analisa data multivariat menggunakan $\mathrm{Uji}$ LSD (Least Significant Different) dengan tingkat kesalahan 5\%, jika $\mathrm{F}_{\text {hitung }}>\mathrm{F}_{\text {tabel. }}$. Hal ini dilakukan untuk mengetahui perbedaan yang bermakna diantara konsentrasi antiseptik 2\%, 4\%, 6\%,8\% dan $10 \%$ dalam menghambat pertumbuhan bakteri Echerichia coli.

\section{HASIL}

Sabun antiseptik cair yang digunakan dalam penelitian ini merupakan sabun cuci tangan/hand soap dimana pada kemasannya tertera mengandung $0,05 \%$ triclosan dan terdaftar di Kemenkes. Menurut Badan Pengawasan Obat dan Makanan (BPOM), penggunaan triclosan dalam sediaan sabun, maksimal $0,3 \%$. Jadi kadar triclosan yang terdapat dalam sabun antiseptik cair yang digunakan pada penelitian ini masih dalam batas yang diperbolehkan oleh BPOM.

\section{Uji Daya Hambat}

Kemampuan sabun antiseptik cair yang mengandung triclosan dan terdaftar di BPOM/ Kemenkes dalam menghambat pertumbuhan bakteri Escherichia coli dengan metode difusi agar Kirby-Bauer, didapatkan hasil bahwa antiseptik dengan konsentrasi 2\%, 4\%, 6\%, $8 \%$ dan $10 \%$ dapat menghambat pertumbuhan bakteri Escherichia coli. Hal ini ditandai dengan terbentuknya zona hambat (bening) di sekitar disk, zona hambat ini diukur diameternya dalam 
satuan millimeter. Hal ini membuktikan bahwa kandungan triclosan dalam sabun antiseptik berpotensi untuk menghambat pertumbuhan bakteri (Tabel 1).

Tabel 1. Diameter Zona Hambat Sabun Antiseptik Cair yang Mengandung Triclosan yang Terdaftar di BPOM/ Kemenkes terhadap Pertumbuhan Bakteri Echerichia coli

\begin{tabular}{cccc}
$\begin{array}{c}\text { Konsentrasi } \\
(\%)\end{array}$ & $\begin{array}{c}\text { Jumlah } \\
(\mathbf{m m})\end{array}$ & $\begin{array}{c}\text { Rata- } \\
\text { rata } \\
(\mathbf{m m})\end{array}$ & $\begin{array}{c}\text { Kriteria } \\
\mathbf{( S K}, \mathbf{K}, \mathbf{S} .\end{array}$ \\
\hline 2 & 35,58 & 7.12 & Sedang \\
4 & 37,52 & 7.50 & Sedang \\
6 & 39,15 & 7.83 & Sedang \\
8 & 41,23 & 8.25 & Sedang \\
10 & 42,74 & 8.55 & Sedang \\
Fenol 2\% & 53,2 & 10,64 & Kuat \\
Aquades & 0 & 0,0 & Lemah \\
Keterangan: SK = Sangat Kuat $(>20 \mathrm{~mm}):$ & \\
K = Kuat $(>10-20 \mathrm{~mm}):$ S= Sedang $(5-10 \mathrm{~mm}):$ L $=$ Lemah $(<5 \mathrm{~mm})$
\end{tabular}

Tabel 1 memperlihatkan bahwa, sabun antiseptik konsentrasi $2 \%-10 \%$ yang mengandung triclosan, mampu menghambat pertumbuhan bakteri Escherichia coli, dengan rata-rata diameter zona hambat antara $\quad 7,12 \mathrm{~mm}-8,55 \mathrm{~mm}$, dimana makin tinggi konsentrasi antiseptik, maka makin luas diameter zona hambat yang terbentuk. Berdasarkan kriteria kemampuan antiseptik, maka antiseptik yang mengandung triclosan ini sampai dengan konsentrasi $10 \%$ termasuk kriteria sedang, karena diameter zona hambatnya antara $5 \mathrm{~mm}-10 \mathrm{~mm}$. Diameter zona hambat antiseptik cair yang mengandung triclosan terhadap pertumbuhan bakteri Escherichia coli dapat digambarkan dalam grafik garis berikut ini (Gambar 1).

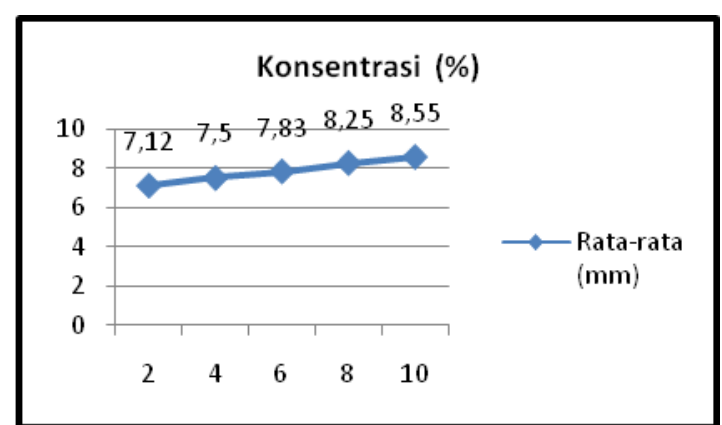

Gambar 1. Grafik diameter zona hambat sabun antiseptik cair yang mengandung triclosan yang terdaftar di BPOM/ Kemenkes terhadap pertumbuhan bakteri Escherichia coli

Grafik pada gambar 1, garis yang naik ke atas mulai dari konsentrasi $2 \%$ sampai dengan $10 \%$, ini menunjukkan bahwa, makin tinggi konsentrasi antiseptik, maka makin luas diameter zona hambat yang terbentuk, atau makin tinggi konsentrasi antiseptik, maka makin besar kesempatan dari antiseptik untuk menghambat pertumbuhan bakteri Escherichia coli.

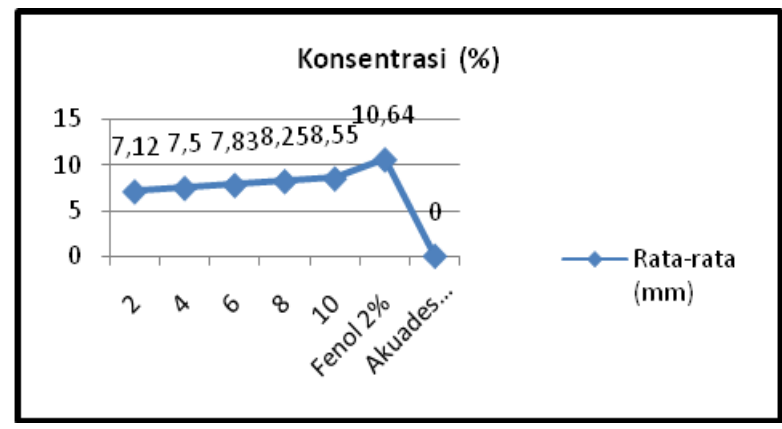

Gambar 2. Grafik diameter zona hambat sabun antiseptik cair yang mengandung triclosan yang terdaftar di BPOM/ Kemenkes terhadap pertumbuhan bakteri Escherichia coli dibandingkan dengan fenol $2 \%$ dan aquades

Grafik garis pada gambar 2 memperlihatkan bahwa kemampuan sabun antiseptik cair yang mengandung triclosan tidak sama kemampuannya dengan fenol $2 \%$ dalam menghambat pertumbuhan bakteri Escherichia coli. Fenol 2\% dapat menghambat pertumbuhan bakteri dengan diameter rata-rata zona hambatnya $10,64 \mathrm{~mm}$ yang berkriteria kuat. Maka antiseptik konsentrasi 2\%-10\% mempunyai daya hambat terhadap bakteri Escherichia coli dibawah kemampuan fenol $2 \%$, sedangkan aquades steril tidak punya kemampuan untuk menghambat pertumbuhan bakteri Escherichia coli karena daya hambatnya $0 \mathrm{~mm}$ dan ini membuktikan bahwa aquades steril sebagai kontrol negatif tidak mengandung antibakteri (Gambar 2).

Analisa bivariat dengan uji Anova dilakukan untuk menentukan apakah daya hambat sabun antiseptik yang mengandung triclosan mempunyai pengaruh yang bermakna terhadap pertumbuhan bakteri Escherichia coli (Tabel 2).

Tabel 2. Uji Anova dari Daya Hambat Sabun Antiseptik Cair yang Mengandung Triclosan yang Terdaftar di BPOM/ Kemenkes terhadap Pertumbuhan Bakteri Escherichia coli

\begin{tabular}{lccccc}
\hline & $\begin{array}{c}\text { Sum of } \\
\text { Squares }\end{array}$ & Df & $\begin{array}{c}\text { Mean } \\
\text { Square }\end{array}$ & $\boldsymbol{F}$ & Sig. \\
\hline $\begin{array}{l}\text { Between } \\
\begin{array}{l}\text { Groups } \\
\text { Within }\end{array}\end{array}$ & 6,514 & 4 & 1.629 & 42,576 & $\mathbf{0 . 0 0 0}$ \\
$\begin{array}{l}\text { Groups } \\
\text { Total }\end{array}$ & 0,765 & 20 & 0.038 & & \\
\hline
\end{tabular}


Diameter zona hambat yang terbentuk dianalisa bivariat menggunakan uji ANOVA (Tabel 2) dengan taraf kepercayaan $95 \%$, hasilnya didapatkan bahwa $p$-value $=0,000$ atau $p$-value $<\alpha$ $(0,05)$, artinya antiseptik cair yang mengandung triclosan yang terdaftar di BPOM/Kemenkes mempunyai pengaruh yang bermakna/signifikan terhadap pertumbuhan bakteri Escherichia coli.

Efektifitas sabun antiseptik cuci tangan yang mengandung triclosan selanjutnya dianalisa dengan uji $\mathrm{T}$ didapatkan hasil $\mathrm{T}$ hitung $>\mathrm{T}$ tabel, ini membuktikan sabun antiseptik cair yang mengandung triclosan dan terdaftar di BPOM/Kemenkes dapat menurunkan angka kuman pada tangan atau dapat membunuh kuman pada tangan (Tabel 3), atau sabun antiseptik ini efektif dalam menurunkan jumlah kuman pada tangan.

Hasil uji multivariat menggunakan uji LSD (Least Significant Different) menunjukkan bahwa tiap konsentrasi sabun antiseptik cair konsentrasi $2 \%, 4 \%, 6 \%, 8 \%$ dan $10 \%$, semuanya mempunyai kemampuan yang berbeda dalam menghambat pertumbuhan bakteri Escherichia coli, karena $p$-value $<\alpha(0,05)$ untuk semua konsentrasi. Sabun antiseptik cair yang mengandung triclosan konsentrasi $2 \%$ berbeda kemampuannya dalam menghambat pertumbuhan bakteri Escherichia coli dengan konsentrasi 4\%, $6 \%, 8 \%$ dan $10 \%$, demikian juga konsentrasi $4 \%$ berbeda kemampuannya dalam menghambat pertumbuhan bakteri Escherichia coli dibandingkan dengan konsentrasi 6\%, $8 \%$ dan $10 \%$ dan begitu juga dengan konsentrasi $6 \%, 8 \%$ dan $10 \%$.

\section{Angka Kuman pada Tangan}

Selain uji sensitivitas, penelitian ini juga melakukan pemeriksaan jumlah kuman metoda ALT (Angka Lempeng Total) pada tangan sebelum dan sesudah dicuci dengan sabun antiseptik cair yang mengandung triclosan dan terdaftar di BPOM/Kemenkes.
Tabel 3. Jumlah Kuman Angka Lempeng Total (ALT) pada Tangan Sebelum Dan Sesudah Dicuci Dengan Sabun Antiseptik Cair Yang Mengandung Triclosan dan Terdaftar di BPOM/ Kemenkes

\begin{tabular}{|c|c|c|}
\hline Probandus & $\begin{array}{l}\text { ALT sebelum } \\
\text { cuci tangan }\end{array}$ & $\begin{array}{l}\text { ALT sesudah } \\
\text { cuci tangan }\end{array}$ \\
\hline 1 & $9,5 \times 10^{2}$ & $6,2 \times 10^{2}$ \\
\hline 2 & $9,1 \times 10^{2}$ & $4,6 \times 10^{2}$ \\
\hline 3 & $6,4 \times 10^{2}$ & $3,1 \times 10^{2}$ \\
\hline 4 & $4,4 \times 10^{2}$ & $3,2 \times 10^{2}$ \\
\hline 5 & $3,2 \times 10^{2}$ & 0 \\
\hline 6 & $3,0 \times 10^{2}$ & 0 \\
\hline 7 & 0 & 0 \\
\hline 8 & $3,8 \times 10^{2}$ & 0 \\
\hline 9 & $7,5 \times 10^{2}$ & $4,7 \times 10^{2}$ \\
\hline 10 & $8,0 \times 10^{2}$ & $3.6 \times 10^{2}$ \\
\hline 11 & $5,6 \times 10^{2}$ & 0 \\
\hline 12 & $3,2 \times 10^{2}$ & $3,2 \times 10^{2}$ \\
\hline 13 & $3,0 \times 10^{2}$ & 0 \\
\hline 14 & 0 & 0 \\
\hline 15 & $3,0 \times 10^{2}$ & 0 \\
\hline 16 & $3,2 \times 10^{2}$ & 0 \\
\hline 17 & $5,8 \times 10^{2}$ & $3,2 \times 10^{2}$ \\
\hline 18 & $8,3 \times 10^{2}$ & $4,1 \times 10^{2}$ \\
\hline 19 & $3,0 \times 10^{2}$ & 0 \\
\hline 20 & $4,7 \times 10^{2}$ & $3,2 \times 10^{2}$ \\
\hline 21 & $5,4 \times 10^{2}$ & 0 \\
\hline 22 & 0 & 0 \\
\hline 23 & $3,2 \times 10^{2}$ & 0 \\
\hline 24 & $3,5 \times 10^{2}$ & 0 \\
\hline 25 & 0 & 0 \\
\hline 26 & $5,2 \times 10^{2}$ & $3,4 \times 10^{2}$ \\
\hline 27 & $6,2 \times 10^{2}$ & $3,9 \times 10^{2}$ \\
\hline 28 & $4,7 \times 10^{2}$ & $3,0 \times 10^{2}$ \\
\hline 29 & $3,2 \times 10^{2}$ & 0 \\
\hline 30 & $3,5 \times 10^{2}$ & 0 \\
\hline Rata-rata & $4,32 \times 10^{2}$ & $1,65 \times 10$ \\
\hline
\end{tabular}

Jumlah angka kuman pada tangan 30 orang probandus sebelum cuci tangan dengan sabun cair antiseptik berjumlah antara $0 \mathrm{~s} / \mathrm{d} 9,5 \times 10^{2}$ koloni, sedangkan sesudah cuci tangan dengan sabun cair antiseptik jumlah kuman pada tangan turun mulai dari $0 \mathrm{~s} / \mathrm{d} 6,2 \times 10^{2}$. Rata-rata jumlah kuman/ALT pada tangan sebelum cuci tangan dengan sabun antiseptik berjumlah $4,32 \times 10^{2}$ (432) koloni, sedangkan rata-rata jumlah kuman/ALT pada tangan sesudah cuci tangan dengan sabun antiseptik berjumlah 1,65x10 (17) koloni, jadi pencucian tangan dengan sabun antiseptik yang mengandung triclosan dapat menurunkan angka kuman sampai dengan $96,18 \%$.

\section{PEMBAHASAN}

Hasil penelitian pada tabel 1 menunjukkan bahwa, sabun antiseptik cair yang mengandung triclosan yang diencerkan dari konsentrasi $2 \%$ s/d 10\% mampu menghambat pertumbuhan 
bakteri Escherichia coli dengan diameter zona $7,12 \mathrm{~mm}$ s/d $8,55 \mathrm{~mm}$, dimana makin tinggi konsentrasi antiseptik, maka semakin besar kemampuannya dalam menghambat pertumbuhan bakteri Escherichia coli, karena makin tinggi konsentari, maka semakin banyak kadar triclosan dalam antiseptik tersebut, sehingga kesempatan untuk membunuh bakteri semakin besar. Menurut Tjay dan Kirana (2007), mekanisme kerja triclosan dalam membunuh bakteri adalah, dengan menghambat biosintesis lipid dari mikroba, lalu membran mikroba kehilangan kekuatan dan fungsinya, sehingga mikroba akan terhambat pertumbuhannya yang berakhir dengan kematian. Tjay dan Kirana (2007) juga menjelaskan bahwa, triclosan mempunyai daya antimikroba dengan spektrum luas, yaitu dapat menghambat pertumbuhan bakteri yang bersifat Gram Positif dan Gram Negatif.

Daya hambat antiseptik yang mengandung triclosan sampai konsentrasi $10 \%$ termasuk kriteria sedang, dibandingakan dengan fenol $2 \%$, kemampuannya masih dibawah fenol $2 \%$, dimana fenol 2\% kuat (Tabel 1 dan Gambar 2). Hal ini disebabkan kandungan antiseptik triclosan yang tercantum dalam kemasan $0,05 \%$, kemudian diencerkan sampai dengan $10 \%$, sehingga konsentrasi triclosan yang diberikan atau yang diujikan pada bakteri Escherichia coli menjadi $0,005 \%$, ini cukup kecil konsentrasinya dibandingkan dengan yang diperbolehkan oleh BPOM maksimal 0,3\%. Menurut Pelezar dan Chan (2005), kerja antibakteri/antiseptik antara lain dipengaruhi oleh konsentrasi atau intensitas zat antibakteri. Semakin tinggi konsentrasi zat yang berperan sebagai antiseptik, maka semakin besar kemampuannya dalam menghambat pertumbuhan bakteri, demikian sebaliknya konsentrasi yang rendah tentu akan kecil kesempatannya untuk menghambat pertumbuhan bakteri. Sedangkan aquades tidak ada respon dalam menghambat pertumbuhan bakteri Escherichia coli, karena aquades tidak mengandung antibakteri atau antiseptik.

Hasil uji Anova menunjukkan p-value yang signifikan dengan nilai 0,000 , artinya $p$ value $<0,05$ atau $<\alpha 5 \%$, nilai tersebut menunjukkan bahwa sabun antiseptik cair yang mengandung triclosan yang diencerkan konsentrasi $2 \%$ s/d 10\%, menunjukkan pengaruh yang bermakna terhadap pertumbuhan bakteri Echerichia coli, atau dapat menghambat pertumbuhan bakteri Escherichia coli (Tabel 2). Hal ini tentu disebabkan karena triclosan yang berperan sebagai zat antiseptik dapat mengganggu proses metabolisme bakteri Escherichia coli dengan cara menghambat sintesa asam lemak, sehingga asam lemak yang diperlukan untuk memproduksi dan membangun dinding sel bakteri tidak terbentuk, sehingga antiseptik masuk ke dalam sel bakteri, yang mengakibatkan bakteri akan mati. Menurut Campbell et al (1996), dinding sel bakteri yang bersifat Gram Negatif (Escherichia coli) mengandung lipopolisakarida yang membantu melindungi bakteri dengan cara menghalangi masuknya antibakteri dalam sel, namun kalau terlalu banyak anti bakteri yang masuk dalam sel dapat merusah lemak yang terdapat pada dinding sel bakteri.

Hasil analisa multivariat dengan uji LSD (Least Significant Different) tingkat kesalahan 5\% didapatkan bahwa, adanya perbedaan yang bermakna antara tiap konsentrasi antiseptik dalam menghambat pertumbuhan bakteri Echerichia coli. Makin tinggi konsentrasi antiseptik, maka makin besar kemampuannya dalam menghambat pertumbuhan bakteri Escherichia coli. karena semakin tinggi konsentrasi tentu semakin banyak kandungan triclosan sebagai antibakteri yang terdapat dalam sabun antiseptik cair tersebut, sehingga akan besar kesempatan triclosan untuk merusak metabolisme dinding bakteri dan masuk dalam sel bakteri untuk membunuh bakteri. Menurut Franklin TJ (2005), beberapa antiseptik dengan konsentrasi yang rendah, menghambat fungsi biokimia membran bakteri, namun tidak akan membunuh bakteri tersebut. Ketika konsentrasi antiseptik tersebut tinggi, komponen antiseptik akan berpenetrasi ke dalam sel mikroba dan mengganggu fungsi normal seluler secara luas, termasuk menghambat biosintesis (pembuatan) makromolekul dan presipitasi protein intraseluler dan asam nukleat (DNA atau RNA), sehingga konsentrasi anti bakteri yang tinggi akan mengakibatkan banyak bakteri yang mati.

Penelitian ini menggunakan antiseptik cair yang mengandung triclosan dan terdaftar di BPOM/Kemenkes dengan bakteri Escherichia coli yan bersifat Gram negatif, hal ini sejalan dengan hasil penelitian Virgiawan (2014), bahwa sabun antiseptik cair konsentrasi $10 \%$ sampai dengan $100 \%$ yang tidak terdaftar di BPOM dan Kemenkes dapat menghambat pertumbuhan bakteri Echerichia coli. Menurut Franklin TJ (2005), triclosan adalah antiseptik yang efektif dan populer, bisa ditemui dalam sabun, obat kumur, deodoran, dan lain-lain. Triclosan mempunyai daya antimikroba dengan spektrum luas artinya dapat melawan berbagai macam bakteri yang bersifat Gram Positif maupun Gram Negatif. 
Penelitian ini juga menghitung jumlah kuman/Angka Lempeng Total (ALT) pada tangan, dimana tangan dicuci dengan sabun antiseptik lalu dibilas dengan aquades steril. Hasilnya didapatkan bahwa, jumlah Angka Lempeng Total pada tangan sebelum dicuci dengan sabun antiseptik cair yang mengandung triclosan dan terdaftar di BPOM/Kemenkes $4,32 \times 10^{2}$ dan sesudah cuci tangan berjumlah $1,65 \times 10$. Hal ini menunjukkan bahwa terjadi penurunan angka kuman sesudah tangan dicuci dengan sabun antiseptik cair sebesar $4,115 \times 10^{2}$ atau penurunan angka kuman $96,18 \%$. (tabel 3). Hal ini menunjukkan bahwa sabun cuci tangan ini cukup efektif dalam menurunkan jumlah kuman pada tangan, sejalan dengan hasil penelitian Burton M et al (2011) bahwa, efek cuci tangan nampaknya tidak tergantung pada spesies bakteri, cuci tangan dengan sabun nonanti bakteri dan air lebih efektif untuk menghilangkan bakteri potensial pada tangan dari pada mencuci tangan dengan air saja, sehingga lebih berguna untuk pencegahan penularan penyakit diare. Hasil penelitian ini berbeda dengan hasil penelitian Girou E et al (2002) bahwa, mencuci tangan saat perawatan pasien rutin dengan larutan berbasis alkohol lebih efektif dalam mengurangi kontaminasi tangan dari pada cuci tangan dengan sabun antiseptik.

Hasil pada tabel 3 menunjukkan bahwa, dari 30 probandus masih terdapat kuman pada tangan sesudah dicuci dengan sabun antiseptik cair yang mengandung triclosan. Penurunan angka kuman atau penurunan jumlah kuman pada tangan $96,18 \%$ atau tidak mencapai $100 \%$, artinya masih ada kuman yang tidak mati oleh sabun cair antiseptik yang mengandung triclosan, hal ini dapat disebabkan karena sudah ada bakteri yang resisten terhadap antiseptik, karena selama ini probandus tidak terukur dalam pengunaan sabun antiseptik.

Efektivitas antiseptik dalam membunuh mikroorganisme bergantung pada beberapa faktor, antara lain konsentrasi dan lama paparan (SS. 2001). Penelitian ini tidak mengamati lamanya waktu kontak antara antiseptik dengan bakteri, dimana lamanya kontak antara bakteri dengan antiseptik dapat memberi kesempatan yang cukup pada antiseptik untuk merusak dinding sel bakteri, sehingga konsentrasi antiseptik yang rendah pun dapat menghambat atau membunuh bakteri lebih banyak. Mengamati lama waktu kontak bersamaan dengan konsentrasi antiseptik, sehingga dapat diketahui lamanya cuci tangan dan konsentrasi yang efektif dalam membunuh bakteri, hal ini dapat dilakukan dengan metoda koefisien fenol.

\section{SIMPULAN}

1. Sabun antiseptik cair mengandung triclosan yang terdaftar di BPOM/ Kemenkes mampu menghambat pertumbuhan bakteri Escherichia coli dengan diameter zona hambat pada konsentrasi 2\%, 4\%, 6\%, 8\% dan $10 \%$ masing-masing adalah $7,12 \mathrm{~mm}, 7,50 \mathrm{~mm}$, $7,83 \mathrm{~mm}, 8,25 \mathrm{~mm}$ dan $8,55 \mathrm{~mm}$

2. Sabun antiseptik cair mengandung triclosan konsentrasi $2 \%, 4 \%, 6 \%, 8 \%$ dan $10 \%$ yang terdaftar di BPOM/Kemenkes berkekuatan sedang dalam menghambat pertumbuhan bakteri Escherichia coli.

3. Dibandingkan dengan fenol $2 \%$ (kontrol positif), sabun antiseptik cair mengandung triclosan konsentrasi 2\%, 4\%, 6\%, 8\% dan $10 \%$ yang terdaftar di BPOM/Kemenkes dalam menghambat pertumbuhan bakteri Escherichia coli masih dibawah fenol 2\%, dimana fenol $2 \%$ termasuk kriteria kuat sedangkan antiseptik yang diuji sampai dengan konsentrasi $10 \%$ berkekuatan sedang.

4. Sabun antiseptik cair mengandung triclosan terdaftar di BPOM/Kemenkes yang paling besar kemampuanya dalam menghambat pertumbuhan bakteri Escherichia coli adalah konsentrasi $10 \%$

5. Jumlah angka kuman/ALT pada tangan sebelum dicuci dengan sabun antiseptik cair mengandung triclosan yang terdaftar di BPOM/Kemenkes adalah 4,32 $\times 10^{2} / 432$ koloni, dan sesudah dicuci adalah 1,65x 10/16,5 koloni.

6. Jumlah penurunan angka kuman dan persentase penurunan angka kuman/ALT pada tangan sesudah tangan dicuci dengan sabun antiseptik cair mengandung triclosan yang terdaftar di BPOM/Kemenkes adalah $4,155 \times 10^{2} / 415,5$ koloni dengan persentase $96,18 \%$.

7. Sabun antiseptik cair mengandung triclosan dan terdaftar di BPOM/ Kemenkes efektif dalam membunuh bakteri pada tangan. 


\section{DAFTAR PUSTAKA}

Burton M, Cobb E, Donachie P, Judah G, Curtis V, Schmidt WP. (2011). The Effect of Handwashing with Water or Soap on Bacterial Contamination of Hands. Int. J. Environ. Res. Public Health. Vol 8. 97104.

Campbell, N. A, J. B. Reece dan L.A, Mitchell. (1996). Biologi. Edisi Kelima, Jilid I, Terjemaham dari Biology. Oleh. Rahayu Lestari, dkk. Jakarta: Erlangga.

Chandra. (2007). Pengantar Kesehatan Lingkungan. Jakarta: Penerbit Buku Kedokteran EGC.

Franklin TJ, Snow GA. (2005). Biochemistry and Molecular Biology of Antimicrobial Drug Action. 6th Edition. New York: Springer Science \& Business Media Inc.

Fardiaz. (1993). Analisis Mikrobiologi Pangan. Jakarta: PR. Raja Grafindo Persada.

Girou E, Loyeau S, Legrand P, Oppein F, BrunBuisson C. (2002). Efficacy of Handrubbing with Alcohol Based Bolution Versus Standard Handwashing With Aanticeptic soap: Randomised Clinical Trial. BMJ. vol 325
Notoatmodjo, Soekidjo. (2005). Metodologi Penelitian Kesehatan. Jakarta: Rineka Cipta.

Nugraha A.P. (2016). Bahaya Dibalik Sabun Antibakteri yang Mengandung Triclosan. http://www.putma.com. Diakses pada 4 Februari 2017.

Pelezar, Michael. \& Chan. (2005). Dasar-Dasar Mikrobiologi. Jakarta: Universitas Indonesia.

Soemarno. (2000). Isolasi dan Identifikasi Bakteri Klinik. Yogyakarta: Akademi Analis Kesehatan Yogyakarta DEPKES RI.

SS. (2001). Disinfection, Sterilization, and Preservation 5th Edition. USA: Lippincott Williams \& Wilkins.

Tjay, Tan Hoan, Kirana Rahardja. (2007). ObatObat Penting Khasiat, Penggunaan dan Efek-Efek Sampingnya. Jakarta: PT. Elex Media Komputindo Kelompok Kompas.

Virgiawan.D.P. (2014), Uji Daya Hambat Sabun Antiseptik Cair Terhadap Pertumbuhan bakteri Echerichia coli, KTI. Poltekkes Tanjungkarang, Bandar Lampung.

Widodo, Wahyu, Sri Sumarsih. (2007). Jarak Kepyar. Yogyakarta: Kanisius. 